УДК 330.341:664

DOI: https://doi.org/10.54929/pmt-issue2-2021-5

\title{
ТЕХНІКО-ТЕХНОЛОГІЧНА МОДЕРНІЗАЦІЯ ПІДПРИЄМСТВ ХАРЧОВОЇ ПРОМИСЛОВОСТІ ЯК ЗАСІБ ПІДВИЩЕННЯ КОНКУРЕНТОСПРОМОЖНОСТІ
}

\section{TECHNICAL AND TECHNOLOGICAL MODERNIZATION \\ OF FOOD INDUSTRY ENTERPRISES AS A MEANS OF INCREASING COMPETITIVENESS}

Лагодієнко В. В.

доктор економічних наук, професор, завідувач кафедрою маркетингу, підприємництва і торгівлі, Одеська національна академія харчових технологій ORCID ID: 0000-0001-9768-5488

Козак К. Б.

доктор економічних наук, доцент, професор кафедри менеджменту та логістики, Одеська національна академія харчових технологій ORCID ID: 0000-0002-8099-6607

Рибалко С. В. доктор економічних наук, доцент кафедри економічної теорії та фрінансово-економічної безпеки, Одеська національна академія харчових технологій ORCID ID: 0000-0001-5449-4147

Volodymyr Lagodiienko Doctor of Economics, Professor, Head of the Department of Marketing, Entrepreneurship and Trade, Odessa National Academy of Food Technologies

\section{Katerina Kozak \\ Doctor of Economics, Associate Professor, Professor of Management and Logistics, Odessa National Academy of Food Technologies}

Serhiy Rybalko Doctor of Economic Sciences, Associate Professor of Economic Theory and Financial and Economic Security, Odessa National Academy of Food Technologies

У статmі проаналізовано показники рівня технологомісткості та техніко-технологічної модернізації підприємств харчової промисловості, обгрунтовано їх вплив на підвищення конкурентоспроможності. Встановлено, що існуючі тенденції інноваційної діяльності підприємств галузі не забезпечують можливостей повноцінної реалізації потенціалу в частині техніко-технологічної модернізації, в результаті чого конкурентні позиції на ринках різних рівнів слабшають. Доведено, що вирішення даної проблеми стане можливим при формуванні належного інституційного середовища, що дозволить задіяти всі необхідні механізми стимулювання техніко-технологічної модернізації на інноваційній основі та прогресивних змін у галузі загалом. Розробка організаційно-економічного механізму, спрямованого на реалізацію конкурентних переваг підприємств харчової промисловості, на цій основі визначає перспективи подальших досліджень. Ключові слова: техніко-технологічна модернізація, технічне оновлення, інноваційні технології, інноваційна діяльність, харчова промисловість.

В статье проанализированы показатели уровня технологоемкости и технико-технологической модернизации предприятий пищевой промышленности, обосновано их влияние на повышение конкурентоспособности. Установлено, что существующие тенденции инновационной деятельности предприятий отрасли не обеспечивают возможности полноценной реализации потенциала в части технико-технологической модернизации, в результате чего конкурентные позиции на рынках разных уровней ослабевают. Доказано, что решение данной проблемы станет возможным при формировании надлежащей институциональной среды, что позволит использовать все необходимые механизмы стимулирования технико-технологиче- 
ской модернизации на инновационной основе и прогрессивных изменений в отрасли в целом. Разработка организационно-экономического механизма, направленного на реализацию конкурентных преимуществ предприятий пищевой промышленности, на этой основе определяет перспективы дальнейших исследований. Ключевые слова: технико-технологичная модернизация, техническое обновление, инновационные технологии, инновационная деятельность, пищевая промышленность.

Achieving the strategic goal of the food industry, namely: the formation of food and economic security, increasing competitiveness in order to enter world food markets, will be possible by solving the problem of technical and technological modernization of material and technical base on an innovative basis. The purpose of the article is to substantiate the priority areas of technical and technological modernization of the food industry in order to increase competitiveness. The study was carried out on the basis of the use of general scientific and specific methods: economic-statistical, systematic approach and generalization, graphical analysis, dialectical and abstract-logical. It was found that the food industry belongs to the category of low-tech industries, is characterized by low rates of reproduction processes, high levels of physical and moral wear of equipment, insufficient technical equipment of production. The results of the technology transfer study show a reduction in such activities; the level of introduction of new or improved types of machines and equipment remains critically low. The number of introduced new technological processes is decreasing, and significantly improved low-waste, resource-saving technologies make up only a third of them. It is established that the existing trends in innovation activities of the industry do not provide opportunities for full realization of potential in terms of technical and technological modernization, innovation activity remains too low, which leads to high labor and energy intensity of production, non-compliance with environmental safety requirements and standards. markets of various levels are weakening. The solution to the problem of increasing the competitiveness of the food industry will be possible with the formation of an appropriate institutional environment, which will use all the necessary mechanisms to stimulate technical and technological modernization on an innovative basis and progressive changes in the industry as a whole. The development of an organizational and economic mechanism aimed at realizing the competitive advantages of the food industry on this basis determines the prospects for further research. Key words: technical and technological modernization, technical renewal, innovative technologies, innovative activity, food industry.

Постановка проблеми у загальному вигляді та їі зв'язок із важливими науковими чи практичними завданнями. Турбулентність змін в національній економіці вимагає підвищення адаптаційних можливостей суб'єктів господарювання харчової промисловості за рахунок підвищення гнучкості реагування на виклики зовнішнього та внутрішнього середовища. Для того, щоб зайняти гідні позиції в умовах посилення конкуренції, підприємствам галузі необхідно запроваджувати нові підходи до вибудовування власної поведінки на ринках. Вирішення цього завдання вбачається можливим лише за умови орієнтації на інноваційну модель розвитку галузі, спрямування наявних ресурсів на підвищення інноваційної активності. Першочергового значення в даному процесі набуває здатність забезпечувати постійне підвищення техніко-технологічного рівня, модернізацію матеріально-технічної бази на інноваційній основі, ефрективне використання знань з метою формування стійких конкурентних переваг. Дана проблема не втрачає своєї актуальності з огляду на зростання темпів збільшення відкритості економіки, посилення інтеграційних процесів, інтенсифрікації входження України до світової агропродовольчої системи.

Аналіз останніх досліджень і публікацій. Теоретичні та практичні засади підвищення конкурентоспроможності харчової промисловості на основі техніко-технологічних нововведень знайшли свій відбиток в науковому доробку таких вчених, як Гадзало Я., Губіна В., Коваленко О., Круглякова В., Сичевський М., Федулова Л., Юринець 3. При- скорення інноваційного розвитку галузі, що передбачає впровадження передових технологій виробництва, визнається потужним чинником створення конкурентних переваг у працях Сичевського М. [1]. Особливої ваги при цьому набуває розбудова технологічної інфрраструктури, що має забезпечити розвиток інтелектуальних і високотехнологічних інновацій [2]. Серед стратегічних векторів та пріоритетних напрямів конкурентоспроможного розвитку харчової промисловості Гадзало Я. надає інноваційній діяльності особливої ваги [3]. Концептуальні основи формування інноваційної системи харчової промисловості в контексті розвитку національної економіки наводяться в дослідженнях Коваленка О. [4], Лагодієнка В. [5, 6]. Губіною В. [7] розробляються механізми підвищення конкурентоспроможності в харчовій промисловості на основі використання сукупності технологічних ресурсозберігаючих нововведень. Вказані ґрунтовні напрацювання слугують підґрунтям для подальших наукових досліджень, спрямованих на вивчення впливу оновлення техніко-технологічної бази підприємств харчової промисловості на формування їхніх конкурентних переваг.

Формулювання цілей статті (постановка завдання). Метою статті $є$ обґрунтування пріоритетних напрямів техніко-технологічної модернізації підприємств харчової промисловості з метою підвищення конкурентоспроможності.

Виклад основного матеріалу дослідження. Реалізація стратегії забезпечення конкурентоспроможності підприємств харчової промисловості можлива лише за умови орієнтації на інноваційну 
модель розвитку. Ключову роль при цьому відіграє забезпечення прогресивних зрушень на основі підвищення техніко-технологічного рівня. За класифікацією Євростату, промислові виробництва за рівнем технологічності поділяються на чотири групи: високотехнологічні, середньо-високотехнологічні, середньо-низькотехнологічні та низькотехнологічні. Такий розподіл здійснюється відповідно до двох критеріїв: рівня технологомісткості та частки працівників з вищою освітою. Для високотехнологіч- них виробництв частка витрат на науково-дослідні і дослідно-конструкторські роботи у доданій вартості, створеній в галузі (рівень технологомісткості) перевищує 5\%, для середньотехнологічних виробництв перебуває у межах 3-5\%, для виробництв, які використовують низькі технології, ця частка відповідає 1-3\% наукових витрат у доданій вартості [8, с. 42]. Ретроспективний аналіз показав, що харчова промисловість утримує стійкий статус низькотехнологічної галузі (рис. 1).

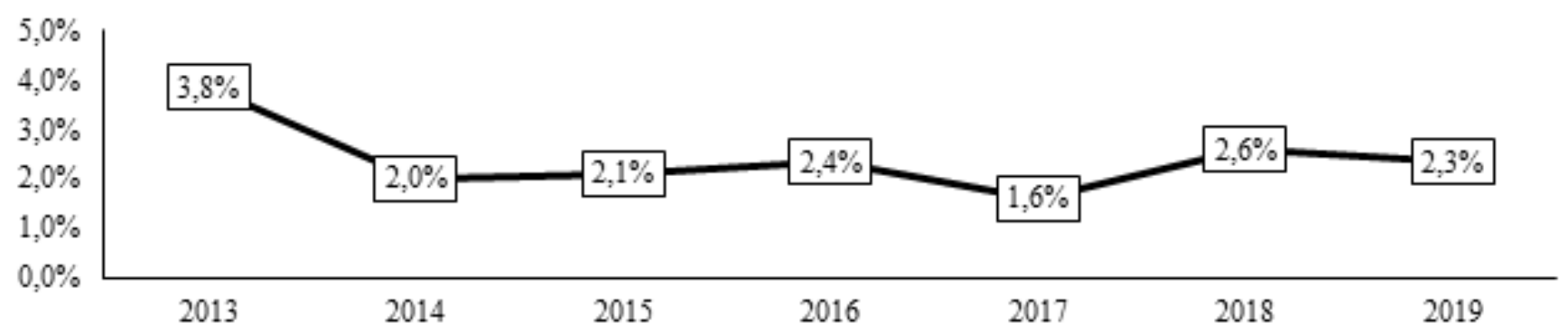

Рис. 1. Динаміка частки витрат на науково-дослідні і дослідно-конструкторські роботи в харчовій промисловості у доданій вартості, створеній в галузі

Джерело: розраховано та побудовано автором за даними [9, 10]

Особливе занепокоєння викликає такий стан справ у зв'язку з тим, що харчова промисловість $€$ структуроутворюючою складовою національної економіки, оскільки її займає п'яту частину в обсязі реалізованої продукції як на внутрішньому ринку, так і за кордоном, причому частка в експорті промислової продукції має тенденцію до збільшення (рис. 2).

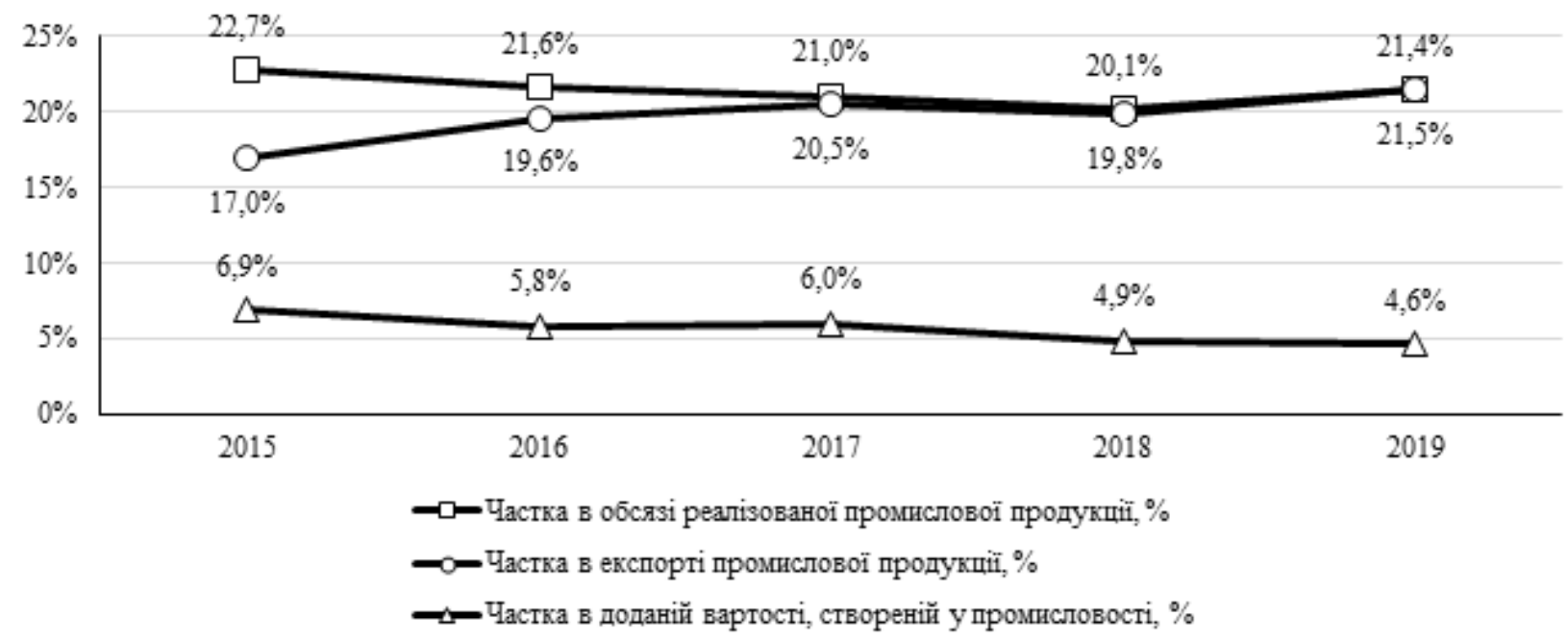

Рис. 2. Динаміка частки харчової промисловості в обсязі реалізованої промислової продукції та в доданій вартості, створеній у промисловості, \%

Джерело: розраховано на побудовано автором за даними [9, 11]

Низький техніко-технологічний рівень стає причиною того, що, незважаючи на значну питому вагу в обсягах реалізації продукції, частка харчової індустрії у створеній в промисловості доданій вартості залишається дуже низькою (4-7\%), загрозливою $є$ динаміка значень цього показника, яка демонструє низхідний тренд. Це свідчить про те, що галузь зберігає та посилює сировинну орієнтацію експорту.

Дослідження свідчать, що переробна промис- ловість, складовою якої є виробництво харчової продукції, може формувати умови інноваційного розвитку та виступати драйвером економічного зростання за умови, якщо структура її виробництва матиме такий вигляд: високотехнологічні підгалузі - 19\%, середньотехнологічні високого рівня $-28 \%$, середньотехнологічні низького рівня - 21\%, низькотехнологічні - 32\% [12]. Ця теза задекларована і в Стратегії розвитку сфери інноваційної діяльності на період до 2030 р., де за- 
значено, що «промисловість зможе бути рушієм прискорення економічного розвитку та якісних змін у структурі економіки лише після суттєвої модернізації, виправлення ситуації зі зношеністю основних засобів та впровадження новацій і переходу до виробництва конкурентоспроможних продуктів із високою часткою доданої вартості» [13].

Основним джерелом техніко-технологічних змін на підприємствах харчової промисловості виступає інноваційна діяльність, провадження якої дозволяє підвищити якість продукції до рівня світових стандартів, зменшити витрати за рахунок впровадження ресурсозберігаючих та малоі безвідходних технологій, забезпечити зростання продуктивності праці, в результаті чого забезпечується високий рівень конкурентоспроможності. Аналіз тенденцій та результатів інноваційної діяльності в харчовій промисловості демонструє неготовність підприємств галузі забезпечувати високі вимоги до технологічного рівня (табл. 1).

Таблиця 1

Характеристика окремих аспектів інноваційної діяльності підприємств харчової промисловості України

\begin{tabular}{|c|c|c|c|c|c|}
\hline \multirow[b]{2}{*}{ Показники } & \multicolumn{5}{|c|}{ У харчовій промисловості } \\
\hline & $\frac{i}{\frac{2}{0}}$ & $\frac{\varrho}{0}$ & $\frac{2}{\frac{2}{\delta}}$ & $\frac{\infty}{\infty}$ & $\frac{\stackrel{0}{a}}{\stackrel{D}{0}}$ \\
\hline Частка інноваційно активних підприємств, \% & 18,1 & 18,9 & 17,8 & 19,8 & 17,2 \\
\hline $\begin{array}{l}\text { Частка підприємств, що впроваджували нову або значно вдо- } \\
\text { сконалену продукцію, \% }\end{array}$ & 10,9 & 20,8 & 12,0 & 26,0 & 57,3 \\
\hline $\begin{array}{l}\text { Частка підприємств, що реалізували інноваційну продукцію, в } \\
\text { загальній їх кількості, \% }\end{array}$ & 14,5 & 16,0 & 12,5 & 17,5 & 10,6 \\
\hline В т.ч. нову для ринку & 2,3 & 4,0 & 2,7 & 4,7 & 2,9 \\
\hline в т.ч. нову для підприємства & 13,7 & 12,9 & 9,9 & 14,9 & 9,0 \\
\hline $\begin{array}{l}\text { Частка інноваційної продукції в загальному обсязі реалізованої } \\
\text { промислової продукції, \% }\end{array}$ & н.д. & н.д. & 0,9 & 1,0 & 0,9 \\
\hline
\end{tabular}

Джерело: розраховано за даними Державної служби статистки України [10]

Констатуючи зниження інноваційної активності, слід зазначити, що збереження існуючих конкурентних переваг та нарощування конкурентного потенціалу вимагає прискорення технікотехнологічного оновлення підприємств, яке передбачає проведення модернізації виробничої бази, підвищення технічної озброєності суб'єктів господарювання, впровадження нових ресурсоощадних та екологобезпечних технологій. Харчова промисловість характеризується низькими темпами відтворювальних процесів, високим рівнем фрізичного і морального зносу обладнання та устаткування, недостатньою технічною озброєністю виробництва (табл. 2).

Таблиця 2

Динаміка показників відтворення основних засобів у харчовій промисловості

\begin{tabular}{|c|c|c|c|c|c|}
\hline Показники & $\mathbf{2 0 1 5}$ p. & $\mathbf{2 0 1 6}$ p. & $\mathbf{2 0 1 7}$ p. & $\mathbf{2 0 1 8}$ p. & $\mathbf{2 0 1 9}$ p. \\
\hline Коефріцієнт вибуття & 0,19 & 0,12 & 0,04 & 0,07 & 0,05 \\
\hline Коефріцієнт оновлення & 0,27 & 0,24 & 0,19 & 0,03 & 0,22 \\
\hline Коефріцієнт приросту & 0,16 & 0,09 & 0,19 & 0,28 & 0,07 \\
\hline Коефіцієнт зносу & 47,5 & 51,1 & 50,6 & 48,3 & 57,8 \\
\hline
\end{tabular}

Джерело: розраховано за даними Державної служби статистки України [14]

Наведені дані ілюструють незадовільні тенденції у відтворювальних процесах в харчовій промисловості. Незважаючи на наявність приросту технічного озброєння, гострою залишається проблема високого рівня зношеності основних засобів - рівень амортизації наближається до 60\%, причому значення його має схильність до збільшення. На тлі поступового зменшення коефріцієнту вибуття це свідчить про те, що на підприємствах галузі продовжується накопичення застарілого облад- нання. Недостатній рівень техніко-технологічного забезпечення, механізації та автоматизації виробництва призводить до того, що понад $30 \%$ працівників на вітчизняних підприємствах харчової промисловості використовують ручну працю, рівень продуктивності праці відстає від розвинутих країн Західної Європи майже в 4 рази [15, с. 111]. Це викликає необхідність невідкладного здійснення модернізації та технічного та технологічного оновлення матеріально-технічної та технологіч- 
ної бази суб’єктів господарювання, оскільки без впровадження високопродуктивного обладнання та устаткування, нових технологій забезпечення високих конкурентних позицій на ринку стає неможливим.

Доведення стану техніко-технологічного озброєння до рівня, що відповідатиме світовим стандартам та забезпечуватиме конкурентоспроможність як на внутрішньому, так і на світовому ринку, вимагає фрінансового забезпечення та значних вкладень. Харчова індустрія наразі залучає близько $20 \%$ всіх вкладень в промисловість, однак темпи росту обсягів капітальних інвестицій останніми роками коливаються в діапазоні 0,9-1,1, причому незадовільною залишається їх відтворювальна структура - співвідношення розподілу інвестиційних вкладень за напрямками: на нове будівництво, реконструкцію і технічне переозброєння діючого виробництва, розширення діючого виробництва, модернізацію [16]. Значна частина інвестицій спрямовується на забезпечення ремонту та підтримки технічного стану діючих потужностей, амортизаційні відрахування не використовуються на реноваційні цілі, тобто вкладення мають екстенсивний характер та мають недостатній рівень інноваційної спрямованості.

Наслідком існуючого становища $€$ те, що показники інноваційної активності підприємств харчової промисловості в частині техніко-технологічної модернізації залишаються на занадто низькому рівні, більшість з них потребує кардинального оновлення. Це зумовлено тим, що сучасне конкурентне середовище вимагає використання новіт- ніх технологій, високопродуктивного обладнання та устаткування (табл. 3).

Концепцією розвитку національної інноваційної системи передбачено збільшення до 2025 року частки інноваційної продукції в обсязі виробництва промислової продукції до 50\%; частки інноваційних підприємств - до 60\%; обсяг експорту високотехнологічної продукції - у 5-7 разів [17]. Однак тенденції останніх років показують невтішні результати інноваційної діяльності харчових підприємств. Зменшується, порівняно з попереднім періодом, кількість впроваджуваних нових технологічних процесів, причому суттєво поліпшені маловідходні, ресурсозберігаючі технології становлять лише третину з них. Натомість більш активно підприємства галузі впроваджують продуктові інновації, реалізація яких вимагає суттєво менших затрат та забезпечує отримання короткострокової віддачі. Це дозволяє в короткі терміни активніше вступати в конкурентну боротьбу та отримувати додаткові конкурентні переваги, однак в довгостроковій перспективі така тактика себе не виправдовує. Критично низьким залишається рівень впровадження нових або вдосконалених видів машин, обладнання: близько $2 \%$ від загальної кількості упроваджених видів інноваційної продукції. Результати дослідження трансфреру технологій демонструють скорочення такої діяльності, причому за кордоном придбається мізерна, як для масштабів країни, їх кількість. В той же час, незважаючи на значний потенціал у сфері НДДКР, за межі України у 2019 р. не було передано жодної технології в галузі харчової промисловості.

Таблиця 3

Динаміка показників техніко-технологічної модернізації підприємств харчової промисловості на інноваційній основі

\begin{tabular}{|c|c|c|c|c|c|}
\hline Показники & 2015 p. & 2016 p. & 2017 p. & 2018 p. & 2019 p. \\
\hline $\begin{array}{l}\text { Кількість упроваджених у виробництво нових } \\
\text { технологічних процесів, всього, од. }\end{array}$ & 116 & 231 & 275 & 204 & 159 \\
\hline $\begin{array}{l}3 \text { них нових або суттєво поліпшених маловід- } \\
\text { ходних, ресурсозберігаючих, } \\
\text { од. } \\
\%\end{array}$ & $\begin{array}{c}41 \\
35,3\end{array}$ & $\begin{array}{c}44 \\
19,0\end{array}$ & $\begin{array}{c}96 \\
34,9\end{array}$ & $\begin{array}{c}89 \\
43,6\end{array}$ & $\begin{array}{c}59 \\
37,2\end{array}$ \\
\hline $\begin{array}{l}\text { Кількість упроваджених видів інноваційної } \\
\text { продукції, всього, од. }\end{array}$ & 445 & 885 & 563 & 893 & 591 \\
\hline $\begin{array}{l}3 \text { них нових та/або вдосконалених видів ма- } \\
\text { шин, обладнання, од. } \\
\%\end{array}$ & $\begin{array}{r}10 \\
2,2\end{array}$ & $\begin{array}{c}17 \\
1,9\end{array}$ & $\begin{array}{r}12 \\
2,1\end{array}$ & $\begin{array}{c}14 \\
1,6\end{array}$ & $\begin{array}{c}73 \\
12,4\end{array}$ \\
\hline Кількість придбаних нових технологій & 91 & 93 & 99 & 76 & 60 \\
\hline в т.ч. за межами України & 6 & 8 & 11 & 8 & 6 \\
\hline
\end{tabular}

Джерело: розраховано за даними Державної служби статистки України [10]

3 огляду на зазначене, можна зробити висновок, що при збереженні наявних темпів та масштабів техніко-технологічної модернізації для підприємств харчової індустрії стає проблематичним не лише забезпечення покращення конкурентних позицій, а й утримання існуючих. Поглиблений аналіз зазначеної проблематики [18, с. 131-137] дозволив сорормувати переконання в тому, що навіть при найбільш сприятливих макроекономічних умовах та ринковому середовищі без відповідного інституційного регулювання досягти належного техніко-технологічного рівня розвитку 
підприємств, що виробляють продовольство, немає можливості. Система підтримки технологічного розвитку галузі має базуватись, насамперед, на розробці, прийнятті та імплементації галузевих програм, які будуть спрямовані на перехід до нового технологічного укладу, що дозволить створювати високоякісну продукцію, гарантувати необхідний рівень національної продовольчої безпеки та забезпечувати конкурентоспроможність з урахуванням сучасних викликів.

Значний потенціал сприяння технікотехнологічній модернізації харчових підприємств на інноваційній основі закладений також у використанні можливостей, які дає організація діяльності технологічних платформ. Технологічна платформа - це «незалежне від інших партнерство, що спрямоване на розвиток науково-дослідних і експериментально-виробничих сегментів наукоємної сфрери економіки, активізацію зусиль по створенню перспективних комерційних технологій, нових продуктів (послуг), залучення додаткових ресурсів для проведення досліджень та розробок на основі участі всіх зацікавлених сторін (бізнесу, науки, влади, суспільства)» [19, с. 60]. Реалізація подібних проєктів у сфері виробництва продовольчої продукції дозволятиме концентрувати і об'єднувати зусилля науки, бізнесу та державних структур, спрямовані на зростання можливостей техніко-технологічного розвитку, підвищення технологічного рівня та екологічності виробництва, мобілізацію інвестиційних ресурсів, що матимуть прогресивну відтворювальну структуру, спрямовуватимуться на освоєння новітніх технологій та розробку й використання модернізованих та принципово нових технічних засобів.
Висновки 3 цього дослідження і перспективи подальших розвідок у даному напрямку. Результати проведеного дослідження дозволяють ссрормулювати певні висновки. Досягнення стратегічної мети, яка стоїть перед підприємствами харчової промисловості, а саме: фрормування продовольчої й економічної безпеки, підвищення конкурентоспроможності з метою входження на світові ринки продовольства, стане можливим при вирішенні завдання техніко-технологічної модернізації матеріально-технічної бази на інноваційній основі. Сучасні реалії свідчать про те, що харчова промисловість належить до категорії низькотехнологічних галузей, характеризується низькими темпами відтворювальних процесів, високим рівнем фрізичного й морального зносу обладнання та устаткування, недостатньою технічною озброєністю виробництва. Існуючі тенденції інноваційної діяльності підприємств галузі не забезпечують можливостей повноцінної реалізації потенціалу в частині технікотехнологічної модернізації, інноваційна активність залишається занадто низькою, що спричиняє високу трудомісткість та енергоємність виробництва, невідповідність вимогам та стандартам екологобезпечності, в результаті чого конкурентні позиції на ринках різних рівнів слабшають. Вирішення проблеми підвищення конкурентоспроможності підприємств харчової промисловості стане можливим при формуванні належного інституційного середовища, що дозволить задіяти всі необхідні механізми стимулювання їхньої техніко-технологічної модернізації на інноваційній основі та прогресивних змін в галузі в цілому. Розробка організаційноекономічного механізму, спрямованого на реалізацію конкурентних переваг підприємств харчової промисловості на цій основі, визначає перспективи подальших досліджень.

\section{БІБЛІОГРАФІЧНИЙ СПИСОК:}

1. Сичевський М.П., Коваленко О.В., Куць О.І., Юзефович А.Е., Ященко Л.О. Інноваційна конкурентоспроможність харчової промисловості України в глобальних вимірах сучасності: концепція зростання та шляхи досягнення : монографія. 2020. Київ. 142 с.

2. Сичевський М. П., Коваленко О. В. Чинники інноваційної конкурентоспроможності харчової промисловості в контексті глобалізації. Економіка АПК. 2016. № 11. C. 60-67. URL : http://nbuv.gov.ua/UJRN/E_apk_2016_11_12

3. Харчова промисловість України: стратегічні аспекти розвитку: монографія / за заг. ред. акад. НААН Я. М. Гадзала; Інститут продовольчих ресурсів НААН. К.: Аграр. наука, 2016. 380 с.

4. Коваленко О. В. Інновації та бізнес у харчовій промисловості: монографія. К.: НHЦ «ІАЕ», 2015. 300 c.

5. Лагодієнко В. В., Завгородній А. В., Шаповалова І. О. Технологічні інновації в забезпеченні конкурентоспроможності підприємств харчової промисловості. Вісник Хмельницького національного університету. Економічні науки. 2020, № 6. С. 291-397. https://www.doi.org/10.31891/2307-5740-2020-288-6-48

6. Лагодієнко В. В., Завгородній А. В., Лагодієнко В. В. Інноваційні аспекти формування конкурентоспроможності підприємств харчової промисловості. Вісник Хмельницького національного університету. Економічні науки. 2021. №1. C. 203-209. https://www.doi.org/10.31891/2307-5740-2021-290-1-36

7. Губіна В.В. Механізми підвищення конкурентоспроможності підприємств харчової промисловості: монографія. Харків: Панов, 2015. 204 с.

8. Соколова О. Роль технологічної структури переробної промисловості у забезпеченні інноваційної моделі розвитку економіки України. Підприємництво та інновації. 2021. № 16. С 39-45. https://doi.org/10.37320/2415$3583 / 16.6$

9. Додана вартість за витратами виробництва суб'єктів господарювання за видами економічної діяльності у 2013-2019 роках. Державна служба статистики України. URL: http://www.ukrstat.gov.ua.

10. Наукова та інноваційна діяльність в Україні. Державна служба статистики України. URL: http://www. ukrstat.gov.ua. 
11. Обсяг реалізованої промислової продукції (товарів, послуг) за видами економічної діяльності у 20152020 роках. URL: http://www.ukrstat.gov.ua/operativ/operativ2015/ pr/orp_rik/orp_rik_u.htm

12. UNIDO. Industrial Development Report. UNIDO. 2020 URL: https://www.unido.org/resources-publicationsflagship-publications-industrial-development-report-series/idr2020

13. Про схвалення Стратегії розвитку сфери інноваційної діяльності на період до 2030 року. Розпорядження Кабінету Міністрів України від 10 липня 2019 р. № 526-p. URL: https://zakon.rada.gov.ua/laws/show/526-2019$\%$ D1\%80\#n12

14. Наявність і стан основних засобів за видами економічної діяльності. Державна служба статистики України. URL: http://www.ukrstat.gov.ua

15. Коткова Н. С. Техніко-технологічне оновлення харчової промисловості України: чинники інвестиційно-інноваційного розвитку. Проблеми економіки. 2013. № 4. C. 108-115. URL: http://nbuv.gov.ua/UJRN/ Pekon_2013_4_15.

16. Капітальні інвестиції підприємств за видами економічної діяльності у 2010-2019 роках. Державна служба статистики України. URL: http://www.ukrstat.gov.ua

17. Про схвалення Концепції розвитку національної інноваційної системи. Розпорядження Кабінету Міністрів України від 17.06. 2009 р. № 680-p. URL: zakon.rada.gov.ua/laws/show/680-2009-p

18. Наумов О. Б., Стоянова-Коваль С. С. Стратегічні пріоритети інституційного регулювання інноваційного розвитку харчової промисловості. Наукові записки Інституту законодавства Верховної Ради України. 2017. № 1. C. 131-137. URL: http://nbuv.gov.ua/UJRN/Nzizvru_2017_1_23

19. Володін С. А. Концептуальні засади створення технологічної платформи інноваційного розвитку АПК «Агротехнополіс». Економіка АПК. 2015. № 8. C. 60-64. URL : http://nbuv.gov.ua/UJRN/E_apk_2015_8_11.

\section{REFERENCES:}

1. Sychevsky, M.P., Kovalenko, O.V., Kuts, O.I., Yuzefovich, A.E., Yashchenko, L.O. (2020). Innovatsiina konkurentospromozhnist kharchovoi promyslovosti Ukrainy $v$ hlobalnykh vymirakh suchasnosti: kontseptsiia zrostannia ta shliakhy dosiahnennia : monohrafiia [Innovative competitiveness of the food industry of Ukraine in the global dimensions of modernity: the concept of growth and ways to achieve: a monograph]. Kyiv. (in Ukrainian).

2. Sychevsky, M.P., Kovalenko, O.V. (2016). Chynnyky innovatsiinoi konkurentospromozhnosti kharchovoi promyslovosti v konteksti hlobalizatsii [Factors of innovative competitiveness of the food industry in the context of globalization]. Ekonomika APK - Economics of agro-industrial complex. 11. 60-67. (in Ukrainian). Accessed at http:// nbuv.gov.ua/UJRN/E_apk_2016_11_12

3. Gadzalo, J. M. (2016). Kharchova promyslovist Ukrainy: stratehichni aspekty rozvytku: monohrafiia [Food industry of Ukraine: strategic aspects of development: a monograph]; Instytut prodovolchykh resursiv NAAN [Institute of Food Resources NAAS]. Kyiv: Agrarian. Science. (in Ukrainian).

4. Kovalenko, O.V. (2015). Innovatsii ta biznes u kharchovii promyslovosti: monohrafiia [Innovations and business in the food industry: a monograph]. Kyiv: NSC «IAE» (in Ukrainian).

5. Lagodiienko, V.V., Zavgorodniy, A.V., Shapovalova, I.O. (2020). Tekhnolohichni innovatsii v zabezpechenni konkurentospromozhnosti pidpryiemstv kharchovoi promyslovosti [Technological innovations in ensuring the competitiveness of the food industry]. Visnyk Khmelnytskoho natsionalnoho universytetu. Ekonomichni nauky Bulletin of Khmelnytsky National University. Economic sciences. 6. 291-397. https://www.doi.org/10.31891/23075740-2020-288-6-48 (in Ukrainian).

6. Lagodiienko, V.V., Zavgorodniy, A.V., Lagodienko, V. V. (2021). Innovatsiini aspekty formuvannia konkurentospromozhnosti pidpryiemstv kharchovoi promyslovosti [Innovative aspects of forming the competitiveness of the food industry]. Visnyk Khmelnytskoho natsionalnoho universytetu. Ekonomichni nauky-Bulletin of Khmelnytsky National University. Economic sciences. 1. 203-209. (in Ukrainian). https://www.doi.org/10.31891/2307-5740-2021290-1-36

7. Gubina, V.V. (2015). Mekhanizmy pidvyshchennia konkurentospromozhnosti pidpryiemstv kharchovoi promyslovosti: monohrafiia [Mechanisms for increasing the competitiveness of food industry enterprises: monograph]. Kharkiv.(in Ukrainian).

8. Sokolova, O. (2021). Rol tekhnolohichnoi struktury pererobnoi promyslovosti u zabezpechenni innovatsiinoi modeli rozvytku ekonomiky Ukrainy. [The role of the technological structure of the processing industry in providing an innovative model of economic development of Ukraine]. Pidpryiemnytstvo ta innovatsii -Entrepreneurship and Innovation. 16. 39-45. https://doi.org/10.37320/2415-3583/16.6 (in Ukrainian).

9. Dodana vartist za vytratamy vyrobnytstva subiektiv hospodariuvannia za vydamy ekonomichnoi diialnosti u 2013-2019 rokakh. [Value added at factor costs of business entities by type of economic activity in 2013-2019]. Derzhavna sluzhba statystyky Ukrainy [State Statistics Service of Ukraine]. (in Ukrainian). Accessed at http://www. ukrstat.gov.ua

10. Naukova ta innovatsiina diialnist $v$ Ukraini [Scientific and innovative activity in Ukraine. (2015-2019)]. Derzhavna sluzhba statystyky Ukrainy [State Statistics Service of Ukraine]. (in Ukrainian). Accessed at http://www. ukrstat.gov.ua.

11. Obsiah realizovanoi promyslovoi produktsii (tovariv, posluh) za vydamy ekonomichnoi diialnosti u 2015-2020 rokakh [The volume of sold industrial products (goods, services) by type of economic activity in 2015-2020]. (in Ukrainian). Accessed at http://www.ukrstat.gov.ua/operativ/operativ2015/pr/orp_rik/orp_rik_u.htm 
12. UNIDO. (2020). Industrial Development Report. UNIDO. 2020. Accessed at https://www.unido.org/resourcespublications-flagship-publications-industrial-development-report-series/idr2020.

13. Pro skhvalennia Stratehii rozvytku sfery innovatsiinoi diialnosti na period do 2030 roku. Rozporiadzhennia Kabinetu Ministriv Ukrainy [On approval of the Strategy for the development of innovation for the period up to 2030. Order of the Cabinet of Ministers of Ukraine] dated July 10, 2019 No. 526-r. (in Ukrainian). Accessed at https://zakon. rada.gov.ua/laws/show/526-2019-\%D1\%80\#n12

14. Naiavnist i stan osnovnykh zasobiv za vydamy ekonomichnoi diialnosti. [Availability and condition of fixed assets by type of economic activity]. (2015-2019). Derzhavna sluzhba statystyky Ukrainy [State Statistics Service of Ukraine]. (in Ukrainian). Accessed at http://www.ukrstat.gov.ua.

15. Kotkova, N.S. (2013). Tekhniko-tekhnolohichne onovlennia kharchovoi promyslovosti Ukrainy: chynnyky investytsiino-innovatsiinoho rozvytku. [Technical and technological renewal of the food industry of Ukraine: factors of investment and innovation development]. Problemy ekonomiky - Problems of the Economy. 4. 108-115. (in Ukrainian). Accessed at http://nbuv.gov.ua/UJRN/Pekon_2013_4_15

16. Kapitalni investytsii pidpryiemstv za vydamy ekonomichnoi diialnosti u 2010-2019 rokakh [Capital investment of enterprises by type of economic activity in 2010-2019]. Derzhavna sluzhba statystyky Ukrainy [State Statistics Service of Ukraine]. (in Ukrainian). Accessed at http://www.ukrstat.gov.ua

17. Pro skhvalennia Kontseptsii rozvytku natsionalnoi innovatsiinoi systemy. Rozporiadzhennia Kabinetu Ministriv Ukrainy [On approval of the Concept of development of the national innovation system. Order of the Cabinet of Ministers of Ukraine] from 17.06. 2009 № 680-r. (in Ukrainian). Accessed at zakon.rada.gov.ua/laws/show/680-2009-p

18. Naumov, O.B., Stoyanova-Koval, S.S. (2017). Stratehichni priorytety instytutsiinoho rehuliuvannia innovatsiinoho rozvytku kharchovoi promyslovosti. [Strategic priorities of institutional regulation of innovative development of the food industry]. Naukovi zapysky Instytutu zakonodavstva Verkhovnoi Rady Ukrainy - Scientific notes of the Institute of Legislation of the Verkhovna Rada of Ukraine. 1, 131-137. (in Ukrainian). Accessed at http:// nbuv.gov.ua/UJRN/Nzizvru_2017_1_23

19. Volodin, S.A. (2015). Kontseptualni zasady stvorennia tekhnolohichnoi platformy innovatsiinoho rozvytku APK «Ahrotekhnopolis» [Conceptual principles of creating a technological platform for innovative development of agro-industrial complex «Agrotechnopolis»]. Ekonomika APK - Economics of agro-industrial complex. 8. 60-64. (in Ukrainian). Accessed at http://nbuv.gov.ua/UJRN/E_apk_2015_8_11 